\title{
The heat capacity of a natural monticellite and phase equilibria in the system $\mathrm{CaO}-\mathrm{MgO}-\mathrm{SiO}_{2}-\mathrm{CO}_{2}{ }^{*}$
}

\author{
Z. D. Sharp, ${ }^{1}$ E. J. ESSEne, ${ }^{1}$ L. M. Anovitz, ${ }^{1}$ G. W. Metz, ${ }^{1}$ E. F. Westrum, JR., ${ }^{2}$ \\ B. S. HEMINGWAY ${ }^{3}$ and J. W. VALLEY \\ ${ }^{1}$ Department of Geological Sciences, University of Michigan, Ann Arbor, MI 48109, U.S.A. \\ ${ }^{2}$ Department of Chemistry, University of Michigan, Ann Arbor, MI 48109, U.S.A \\ ${ }^{3}$ United States Geological Survey, 959 National Center, Reston, VA 22092, U.S.A. \\ ${ }^{4}$ Department of Geology and Geophysics, University of Wisconsin, Madison, WI 53706, U.S.A.
}

(Received November 19, 1985; accepted in revised form April 7, 1986)

\begin{abstract}
The heat capacity of a natural monticellite $\left(\mathrm{Ca}_{1.00} \mathrm{Mg}_{.91} \mathrm{Fe}_{.09} \mathrm{Mn}_{.01} \mathrm{Si}_{0.99} \mathrm{O}_{3.99}\right)$ measured between 9.6 and $343 \mathrm{~K}$ using intermittent-heating, adiabatic calorimetry yields $C_{p}^{0}(298)$ and $S_{298}^{0}$ of $123.64 \pm 0.18$ and $109.44 \pm 0.16 \mathrm{~J} \cdot \mathrm{mol}^{-1} \mathrm{~K}^{-1}$ respectively. Extrapolation of this entropy value to end-member monticellite results in an $S_{298}^{0}=108.1 \pm 0.2 \mathrm{~J} \cdot \mathrm{mol}^{-1} \mathrm{~K}^{-1}$. High-temperature heat-capacity data were measured between $340-1000 \mathrm{~K}$ with a differential scanning calorimeter. The high-temperature data were combined with the 290-350 K adiabatic values, extrapolated to $1700 \mathrm{~K}$, and integrated to yield the following entropy equation for end-member monticellite $(298-1700 \mathrm{~K})$ :
\end{abstract}

$$
S_{T}^{0}\left(\mathrm{~J} \cdot \mathrm{mol}^{-1} \mathrm{~K}^{-1}\right)=S_{298}^{0}+164.79 \ln T+15.337 \cdot 10^{-3} T+22.791 \cdot 10^{5} T^{-2}-968.94 .
$$

Phase equilibria in the $\mathrm{CaO}-\mathrm{MgO}-\mathrm{SiO}_{2}$ system were calculated from 973 to $1673 \mathrm{~K}$ and 0 to $12 \mathrm{kbar}$ with these new data combined with existing data for akermanite $(A k)$, diopside $(D i)$, forsterite $(F o)$, merwinite $(\mathrm{Me})$ and wollastonite $(\mathrm{Wo})$. The location of the calculated reactions involving the phases $M o$ and $F o$ is affected by their mutual solid solution. A best fit of the thermodynamically generated curves to all experiments is made when the $S_{298}^{0}$ of $M e$ is $250.2 \mathrm{~J} \cdot \mathrm{mol}^{-1} \mathrm{~K}^{-1}$, less than the measured value of $253.2 \mathrm{~J} \cdot \mathrm{mol}^{-1} \mathrm{~K}^{-1}$.

$\mathrm{A}$ best fit to the reversals for the solid-solid and decarbonation reactions in the $\mathrm{CaO}-\mathrm{MgO}-\mathrm{SiO}_{2}-\mathrm{CO}_{2}$ system was obtained with the $\Delta G_{298}^{0}\left(\mathrm{~kJ} \cdot \mathrm{mole}^{-1}\right)$ for the phases $A k(-3667), D i(-3025), F o(-2051), M e(-4317)$ and $M O(-2133)$. The two invariant points $-W o$ and $-F o$ for the solid-solid reactions are located at 1008 $\pm 5 \mathrm{~K}$ and $6.3 \pm 0.1 \mathrm{kbar}$, and $1361 \pm 10 \mathrm{~K}$ and $10.2 \pm 0.2 \mathrm{kbar}$ respectively. The location of the thermodynamically generated curves is in excellent agreement with most experimental data on decarbonation equilibria involving these phases.

\section{INTRODUCTION}

BOWEN (1940) PROPOSED ten decarbonation reactions in the system $\mathrm{CaO}-\mathrm{MgO}-\mathrm{SiO}_{2}-\mathrm{CO}_{2}-\mathrm{H}_{2} \mathrm{O}$ characteristic of progressive metamorphism, which give rise to a petrogenetic grid in pressure-temperature space. Phase relations in the system $\mathrm{CaO}-\mathrm{MgO}-\mathrm{SiO}_{2}-X\left(\mathrm{CO}_{2}\right)$ have since been carefully determined by experimental reversals at moderate pressures and temperatures. Unfortunately, efforts to match thermodynamically generated curves for the solid-solid reactions to the experimental reversals have not been entirely successful (HEIGFSON et al., 1978; VAI.LEY and ESSENE, 1980), and thermodynamic arguments suggest that the experimental reversals for the decarbonation reactions must be in error (TURNER, 1968). VALLEY and ESSENE (1980) fit thermodynamically derived curves to the experimental reversals for the following reactions:

$$
\underset{\text { akermanite }}{\mathrm{Ca}_{2} \mathrm{MgSi}_{2} \mathrm{O}_{7}}=\underset{\text { monticellite }}{\mathrm{CaMgSiO}_{4}}+\mathrm{CaSiO}_{3}
$$

\footnotetext{
* Contribution No. 416 from the Thermodynamics Laboratory, Dept. of Chemistry, and the Mineralogical Laboratory. Dept. of Geological Sciences, University of Michigan.
}

$$
\begin{aligned}
& \mathrm{CaMgSi}_{2} \mathrm{O}_{6}+3 \mathrm{CaMgSiO}_{4} \\
& \text { diopside monticellite } \\
& =2 \mathrm{Ca}_{2} \mathrm{MgSi}_{2} \mathrm{O}_{7}+\mathrm{Mg}_{2} \mathrm{SiO}_{4} \\
& \text { akermanite forsterite } \\
& 2 \mathrm{CaSiO}_{3}+2 \mathrm{CaMgSiO}_{4} \\
& \text { wollastonite monticellite }
\end{aligned}
$$

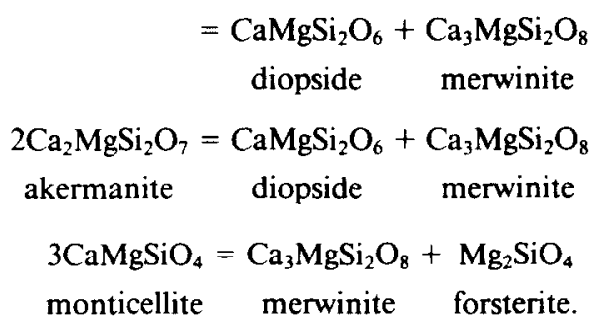

Experiments on reactions (2) and (4) could not be fit with available thermodynamic data for the end-member phases. VALLEY and ESSENE (1980) and BROUSSE et al. (1984) concluded that there must be errors in the entropies of monticellite and either merwinite or akermanite, assuming the reversed experiments are valid. At the time of these studies, the heat capacities of merwinite and akermanite had only heen measured down to $50 \mathrm{~K}$ (WELLER and KELLEY, 1963), whereas the 
heat capacity of monticellite was unmeasured. VALLEY and ESSENE (1980) used the value $1 / 2 S$ (forsterite) $+1 / 2$ $S$ (calcium-olivine) as their entropy estimate for monticellite. More recently, the heat capacity of akermanite has been measured between 9 and $1000 \mathrm{~K}$ (HEMINGWAY et al., 1986) yielding an entropy $3.4 \mathrm{~J} \cdot \mathrm{mol}^{-1} \mathrm{~K}^{-1}$ higher than WELLER and KELLEY's (1963) estimate at $298^{\circ} \mathrm{K}$.

VALLEY and ESSENE analyzed YODER's (1968) run products for reaction (4) in order to evaluate the degree of solid solution and found all phases to be stoichiometric within analytical error. The experiments of SCHAIRER et al. (1967) on the binary joins between akermanite and monticellite, forsterite, wollastonite, merwinite and diopside indicate that none of these phases has more than $1 \%$ solubility in akermanite. On the other hand, monticellite and forsterite exhibit significant mutual solid solution at high temperatures (BIGGAR and O'HARA, 1969; YANG, 1973; WARNER and LUTH, 1973; ADAMS and BisHOP, 1985), which potentially affects equilibrium reversals involving these phases. In order to refine phase relationships in the system $\mathrm{CaO}-\mathrm{MgO}-\mathrm{SiO}_{2}-\mathrm{CO}_{2}$, the volume and beat $\mathrm{ca}$ pacity of a natural monticellite were measured, and corrected for minor element substitution. The run products of YODER (1968) were analyzed to determine the degree of solid solution in akermanite, diopside, forsterite, merwinite and monticellite. With a measured entropy for monticellite, possible errors in the entropy of merwinite can be evaluated by fitting the thermodynamically generated curves to the experiments corrected for solid solutions.

\section{MATERIALS}

Ten grams of clear, glassy monticellite from Cascade Slide, NY (VALLEY and ESSENE, 1980) were separated for analysis. Chemical composition was determined with a fully automated CAMECA CAMEBAX microprobe at The University of Michigan (Tabie 1). The unit-cell volume of the natural material was determined by powder X-ray diffraction at $1 / 2^{\circ} 2 \theta$ / $\min$. with quartz as an internal standard. A least-squares fit of the observed $d$ values of unambiguously indexed peaks (Table 2) yielded the lattice parameters given in Table 3. The molar volume of end-member monticellite was calculated assuming a linear variation between the composition and molar volumes for the phases kirschsteinite, calcium olivine and tephroite (Table 4). The monticellite sample was presumed to be free of vacancies ( $f$. BrowN, 1982) and the analysis was

Table 1. Wontioellite ascroprobe anelysis, Casoade slide, WX.

\begin{tabular}{|c|c|c|c|}
\hline \multicolumn{3}{|c|}{ Oxide Welght Percent } & Dormula \\
\hline 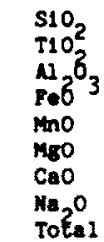 & $\begin{array}{r}36.96 \\
0.02 \\
0.00 \\
3.89 \\
0.39 \\
22.79 \\
34.86 \\
0.01 \\
100.39\end{array}$ & $\begin{array}{l}0 \\
S 1 \\
12 \\
\mathrm{Fe}_{2+} \\
\mathrm{T1} \\
\mathrm{Mr} \\
\mathrm{M} \\
\mathrm{Ca} \\
\mathrm{Na}\end{array}$ & $\begin{array}{l}3.990 \\
0.991 \\
0.000 \\
0.087 \\
0.000 \\
0.911 \\
0.009 \\
1.001 \\
0.000\end{array}$ \\
\hline
\end{tabular}

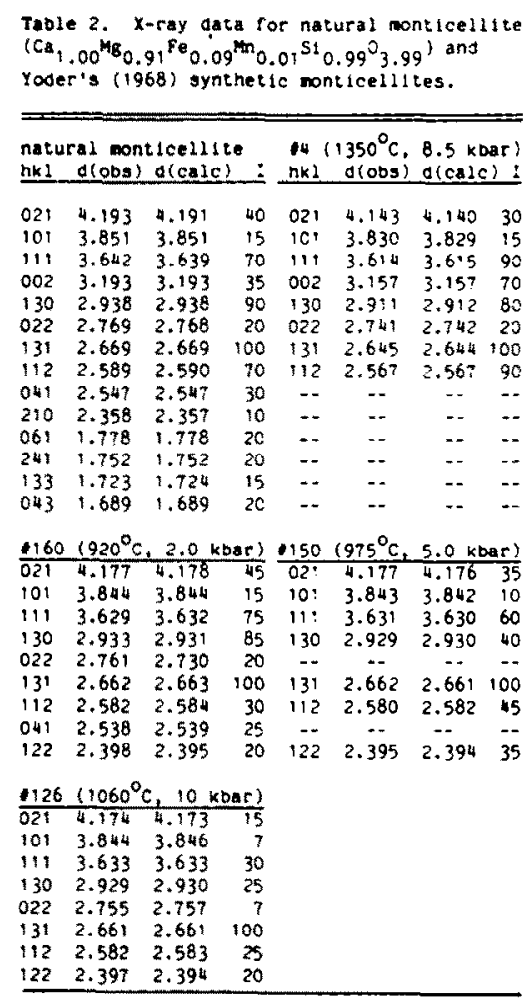

normalized to two octahedral cations. The following equation was solved to obtain the molar volume of pure monticellite:

$$
\begin{aligned}
& \mathrm{Ca}_{0.997} \mathrm{Mg}_{8.907} \mathrm{Fc}_{0.007} \mathrm{Mn}_{0.0009} \mathrm{SiO}_{4}=0.907 \mathrm{CaMgSiO}_{4} \\
& \text { natural monticellite monticellite } \\
& +0.087 \mathrm{CaFeSiO}_{4}+0.0045 \mathrm{Mn}_{2} \mathrm{SiO}_{4}+0.0015 \mathrm{Ca}_{2} \mathrm{SiO}_{4} \text {. } \\
& \text { kirschsteinite tephroitc Ca-olivine }
\end{aligned}
$$

Studies of olivine solid solutions show a nearly linear variation in molar volume between end-member phases (FraNCTS and RIBBE, 1980; LUMPKIN and RJBBE, 1983; LUMPKN $e t$ al., 1983; MUKHOPADHYAY and LiNDSLEY, 1983; FranCTS, 1985). Because of the near-linearity of volumes of different olivine solid-solutions, the results are indiferent to the particular choice of "molecules" in Eqn. 6. The calculated molar volume of $51.48 \pm 0.02 \mathrm{~cm}^{3}$ is in good agreement with other estimates when similarly extrapolated to ideal CaMgSiO. (Table 3). The calculated lattice parameters of the Cascade Slide monticellite are consistent with an ordered phrae when compared with the lattice parameters of BROWN (1982) and LUMPKIN et al. (1983).

\section{HEAT CAPACITY AND ENTROPY OF MONTICELLITE}

The heat capacity of monticellite was measured between 9 and $350 \mathrm{~K}$ in the laboratory of E. F. Westrum, Jr. at the University of Michigan with a low-temperature, intermitientheating, adiabatic calorimeter. Details of the procedure can be found in Westrum et al. (1968) and WESTRUM (1984). The data (Table 5) plot as a smooth sigmate curve with some scatter between 9 and $11 \mathrm{~K}$. The data were extrapolated below $12 \mathrm{~K}$ from a $C, T$ vs. $T^{2}$ plot. Any magnetic transitions below $12 \mathrm{~K}$ due to $\mathrm{Fe}$ and $\mathrm{Mn}$ substituting for $\mathrm{Mg}$ were not considered. The smoothed and integrated date correspond to an entropy at $298.15 \mathrm{~K}$ of $109.44 \pm 0.16 \mathrm{~J} \cdot \mathrm{mol}^{-1} \mathrm{~K}^{-1}$ (Table 6). 
Table 3. Lattice parameters of natural and synthetic tonticellite.

\begin{tabular}{|c|c|c|c|c|c|c|c|c|c|c|}
\hline$x_{C a}$ & $\mathrm{x}_{\mathrm{Mg}}$ & $\mathrm{X}_{\mathrm{Fe}}{ }^{*}$ & $a(R)$ & $b(R)$ & $c(R)$ & $v(8)^{3}$ & $v_{298}^{0}\left(\mathrm{~cm}^{3}\right)$ & $v_{298}^{\circ * *}$ & syn/nat $\mathrm{r}$ & $\mathrm{re}$ \\
\hline 1.00 & 0.91 & 0.09 & $4.828(1)$ & $11.108(2)$ & $6.386(1)$ & $342.50(8)$ & $51.56(1)$ & 51.48 & nat & (1) \\
\hline 0.99 & 1.01 & 0.00 & $4.8209(5)$ & $11.0911(9)$ & $6.3726(6)$ & $340.74(4)$ & $51.299(6)$ & 51.38 & syn. & (2) \\
\hline 1.00 & 0.93 & 0.07 & $4.825(1)$ & $11.111(1)$ & $6.382(2)$ & $342.14(10)$ & $51.51(2)$ & 57.43 & nat. & (3) \\
\hline 0.965 & 1.035 & 0.00 & $4.820(1)$ & $17.075(4)$ & $6.363(1)$ & $339.69(10)$ & $51.15(2)$ & 57.42 & syn. & (4) \\
\hline 1.00 & 1.00 & 0.00 & 4.822 & 11.108 & 6.382 & 341.84 & 51,46 & 31.46 & nat. & (5) \\
\hline 0.95 & 1.05 & 0.00 & $4+823(5)$ & $11.074(7)$ & 5. $367(4)$ & $340.07(28)$ & $53.20(4)$ & 51.50 & syn. & (6) \\
\hline 0.94 & 1.06 & 0.00 & $4.820(5)$ & $11.070(8)$ & $6.363(4)$ & $339.55(21)$ & $5:, 12(4)$ & 51.60 & syn. & $(7)$ \\
\hline 0.945 & 1.055 & 0.00 & $4.839(5)$ & $11.057(10)$ & $6.362(4)$ & $339.69(27)$ & $51.74(4)$ & 51.58 & syn. & (8) \\
\hline 0.85 & 1.15 & 0.00 & $4.815(1)$ & $10.968(2)$ & $6.314(2)$ & $333.51(10)$ & $50.11(2)$ & 51.25 & syn. & (9) \\
\hline
\end{tabular}

The entropy of end-member monticellite was calculated with a procedure analogous to that for molar volume. Entropy data for kirschsteinite are not available, so the entropy of fayalite and calcium-olivine were substituted for kirschsteinite. A linear variation in entropy with composition between natural and end-member monticellite and the phases calcium olivine, tephroite, and fayalite was assumed (Table 4). The magnetic transition contribution to the entropies of fayalite and tephroite were subtracted from the $S_{298}^{0}$ of these phases as the equivalent magnetic entropy contribution to monticellite was smoothed out of the data. The extrapolated $S_{298}^{0}\left(108.1 \pm 0.2 \mathrm{~J} \cdot \mathrm{mol}^{-1}\right.$ $\mathrm{K}^{-1}$ ) compares favorably with the estimate of VALLEY and ESSENE $\left(1980,107.3 \mathrm{~J} \cdot \mathrm{mol}^{-1} \mathrm{~K}^{-1}\right)$, but less favorably with previous estimates (HELGESON et al., $1978,110.5 \mathrm{~J} \cdot \mathrm{mol}^{-1}$ $\mathrm{K}^{-1}$; ROBIE et al., $1978,102.5 \mathrm{~J} \cdot \mathrm{mol}^{-1} \mathrm{~K}^{-1}$ ).

Heat capacity measurements from 340 to $1000 \mathrm{~K}$ were made with a differential scanning calorimeter at the U.S. Geological Survey in Reston, Virginia. These data were fit to the lowtemperature data in the range $290-350 \mathrm{~K}$ and are given in Table 7. The data were smoothed (Table 8, Fig. 1) following the procedure of HEMINGWAY et al. (1981). The following heat capacity equation was fit to the data

$$
\begin{aligned}
& \mathrm{Cp}\left(\mathrm{J} \cdot \mathrm{mol}^{-1} \mathrm{~K}^{-1}\right)=231.404-8.53144 \cdot 10^{-4} T \\
& \quad-1623.422 T^{-0.5}-1.24743 \cdot 10^{6} T^{-2}-1.333 \cdot 10^{-6} T^{2} .
\end{aligned}
$$

An equation for the entropy of end-member monticellite as a function of temperature was calculated by the same procedure for the $S_{298}^{0}$ determination, using compatible entropy coefficients for the phases calcium olivine, tephroite and fayalite (Table 4). Entropy data were extended to $1700 \mathrm{~K}$ using the empirical prediction method of ROBINSON and HAAS (1983) constrained by the measured entropy data below 1000 K. High temperature entropy estimates using mineral summation techniques are within $1.5 \mathrm{~J} \cdot \mathrm{mol}^{-1} \mathrm{~K}^{-1}$ using the following equations:

$$
\begin{gathered}
\mathrm{CaMgSiO}_{4}=2 \mathrm{CaSiO}_{3}+\mathrm{Mg}_{2} \mathrm{SiO}_{4}-\mathrm{CaMgSi}_{2} \mathrm{O}_{6} \\
\text { monticellite wollastonite forsterite diopside } \\
S_{1400 \mathrm{~K}}^{0}=356.9 \mathrm{~J} \cdot \mathrm{mol}^{-1} \mathrm{~K}^{-1} ; \\
\mathrm{CaMgSiO}_{4}=\mathrm{Mg}_{2} \mathrm{SiO}_{4}+\mathrm{CaO}-\mathrm{MgO} \\
\text { monticellite forsterite lime periclase } \\
S_{1400 \mathrm{~K}}^{0}=356.9, \quad S_{1500 \mathrm{~K}}^{0}=370.0 \mathrm{~J} \cdot \mathrm{mol}^{-1} \mathrm{~K}^{-1} .
\end{gathered}
$$

The entropies of monticellite at 1400 and $1500 \mathrm{~K}$ using the technique of ROBINSON and HAAS (1983) are 355.8 and 368.5 $\mathrm{J} \cdot \mathrm{mol}^{-1} \mathrm{~K}^{-1}$ respectively. The following entropy equation is valid in the range $298-1700 \mathrm{~K}$ :

$$
\begin{aligned}
S_{T}^{0}\left(\mathrm{~J} \cdot \mathrm{mol}^{-1} \mathrm{~K}^{-1}\right)-S_{248}^{0} & =164.79 \mathrm{In} T \\
& +15.337 \cdot 10^{-3} T+22.791 \cdot 10^{5} T^{-2}-968.94 .
\end{aligned}
$$

The entropy of $295.1 \mathrm{~J} \cdot \mathrm{mol}^{-1} \mathrm{~K}^{-1}$ at $1000 \mathrm{~K}$ using the above equation is higher than the estimate of $291-293 \mathrm{~J} \cdot \mathrm{mol}^{-1} \mathrm{~K}^{-1}$ using enthalpy data combined with experimental reversals

\begin{tabular}{|c|c|c|c|c|c|c|c|c|}
\hline & $\mathrm{v}_{298}^{0}$ & Source & $s_{298}^{0}$ & A & B & c & D & Source \\
\hline $\begin{array}{l}\text { alctum plivine } \\
\text { ayallte } \\
\text { orsterite } \\
\text { frschstelnite } \\
\text { ontlcellite } \\
\text { ontlcellthe } \\
\text { ephrolte }\end{array}$ & $\begin{array}{l}59.11 \\
46.15 \\
43.65 \\
52.51 \\
51.56 \\
51.48 \\
48.61\end{array}$ & $\begin{array}{ll} & (2) \\
5 & (2) \\
5 & (2) \\
1 & (6) \\
5 & (1) \\
3 & (1) \\
1 & (3)\end{array}$ & $\begin{array}{r}120.50 \\
151.00 \\
94.11 \\
136.02 \\
109.44 \\
108.10 \\
155.90\end{array}$ & $\begin{array}{l}138.32 \\
164.43 \\
146.99 \\
133.37 \\
152.39 \\
164.79 \\
161.71\end{array}$ & $\begin{array}{l}47.6182 \\
26.108 \\
31.291 \\
56.318 \\
29.225 \\
15.337 \\
19.610\end{array}$ & $\begin{array}{r}13.146 \\
18.522 \\
17.344 \\
7.864 \\
17.443 \\
22.791 \\
18.966\end{array}$ & $\begin{array}{l}-817.022 \\
-965.470 \\
-866.35 \\
-785.628 \\
-896.556 \\
-968.940 \\
-948.512\end{array}$ & $\begin{array}{ll}2 & (2) \\
0 & (4) \\
& (5) \\
8 & (7) \\
6 & (1) \\
0 & (1) \\
2 & (5)\end{array}$ \\
\hline \multicolumn{9}{|c|}{ 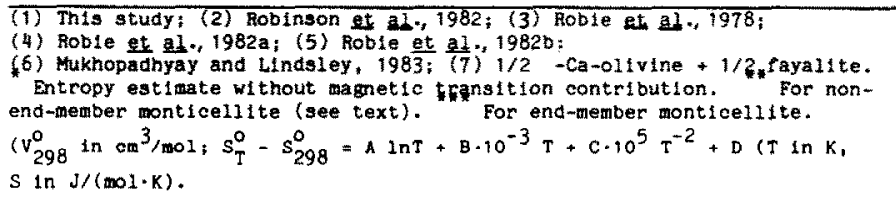 } \\
\hline
\end{tabular}
(BROUSSE et al., 1984).

\section{PHASE EQUILIBRIA IN THE SYSTEM $\mathrm{CaO}-\mathrm{MgO}-\mathrm{SiO}_{2}-\mathrm{CO}_{2}$}

With new data on the entropy of monticellite, we attempted to fit the calculated curves for reactions (15) and the decarbonation reactions

$$
\begin{aligned}
& \mathrm{Mg}_{2} \mathrm{SiO}_{4}+2 \mathrm{CaCO}_{3}+\mathrm{CaMgSi}_{2} \mathrm{O}_{6} \\
& \text { forsterite calcite diopside } \\
& =3 \mathrm{CaMgSiO}_{4}+2 \mathrm{CO}_{2} \\
& \text { monticellite }
\end{aligned}
$$

Table 4. Volume and entropy data for olivine structures. 
Table 5. Experimental low temperature molar heat capacity measurewents on natural monticellite

$\left(\mathrm{Ca}_{1.00^{\mathrm{Mg}}} 0.91^{\mathrm{Fe}} 0.09^{\mathrm{Mn}} 0.01^{\mathrm{Si}} 0.99^{\mathrm{O}} 3.99^{\prime}\right)$

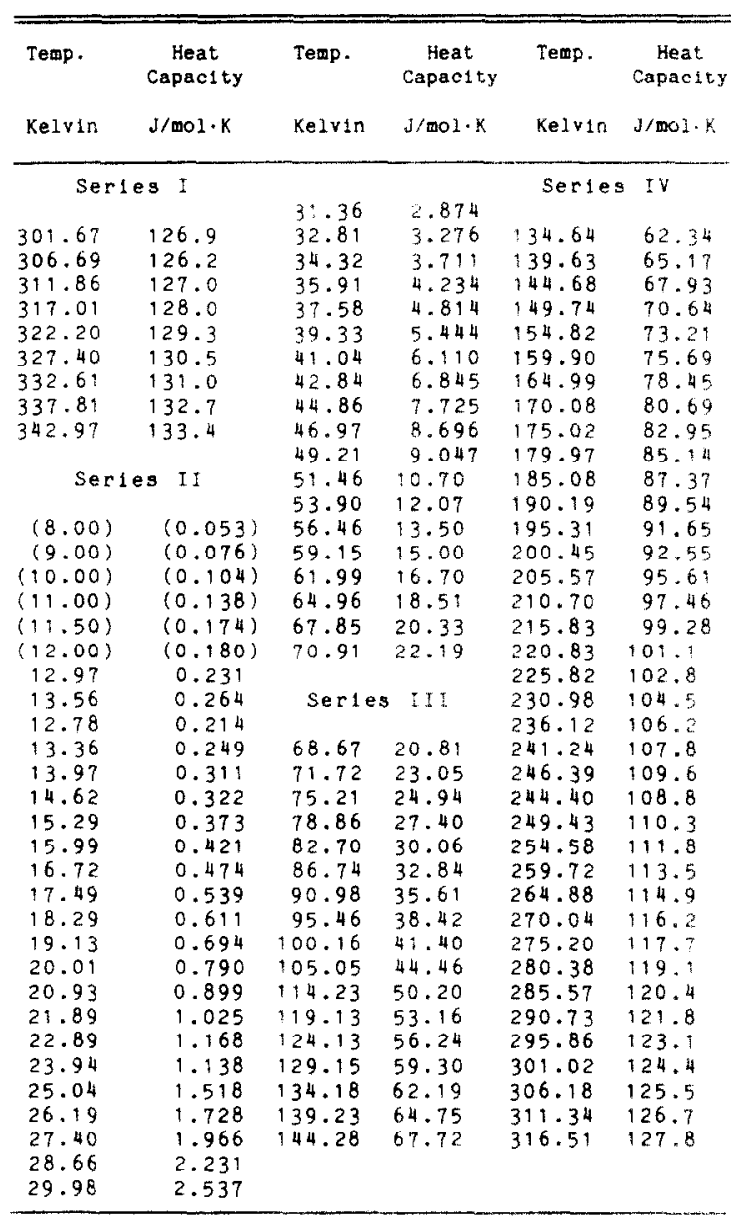

$$
\begin{aligned}
& \mathrm{CaMgSi}_{2} \mathrm{O}_{6}+\mathrm{CaCO}_{3}=\mathrm{Ca}_{2} \mathrm{MgSi}_{2} \mathrm{O}_{7}+\mathrm{CO}_{2} \\
& \text { diopside calcite akermanite }
\end{aligned}
$$

$\mathrm{Ca}_{2} \mathrm{MgSi}_{2} \mathrm{O}_{7}+\mathrm{Mg}_{2} \mathrm{SiO}_{4}+\mathrm{CaCO}_{3}$

akermanite forsterite calcite

$$
\begin{aligned}
= & 3 \mathrm{CaMgSiO}_{4}+\mathrm{CO}_{2} \\
& \text { monticellite }
\end{aligned}
$$

$\mathrm{Mg}_{2} \mathrm{SiO}_{4}+\mathrm{CaCO}_{3}$

forsterite calcite

$$
\begin{aligned}
&= \mathrm{CaMgSiO}_{4}+ \\
& \text { monticellite periclase }
\end{aligned}
$$

$$
\mathrm{Ca}_{2} \mathrm{MgSi}_{2} \mathrm{O}_{7}+\mathrm{CaCO}_{3}=\mathrm{Ca}_{3} \mathrm{MgSi}_{2} \mathrm{O}_{8}+\mathrm{CO}_{2}
$$$$
\text { akermanite calcite merwinite }
$$

to the experimental data. Reactions $(2,5,11,13,14)$ include the phases forsterite and monticellite which display significant mutual solid solution. The location of the end-member curves determined from the ex-

\begin{tabular}{|c|c|c|c|c|}
\hline $\begin{array}{c}\text { Temp. } \\
T\end{array}$ & $\begin{array}{c}\text { Heat } \\
\text { Capaoity } \\
C_{p}^{0}\end{array}$ & $\begin{array}{c}\text { Entropy } \\
s_{\mathrm{T}} \cdot \mathrm{s}_{\mathrm{g}}\end{array}$ & Enthalpy & $\begin{array}{c}\text { atobs } \\
\text { unergy } \\
\text { wriation }\end{array}$ \\
\hline Kelvin & $J / \infty 01 \cdot K$ & $\mathrm{~J} / \mathrm{mol}+\mathrm{k}$ & i/moin $x$ & $4200+3$ \\
\hline 15 & 0.349 & 0.133 & 0.088 & $\because 04:$ \\
\hline 20 & 0.790 & 0.283 & 0.203 & 6.089 \\
\hline 25 & 1.505 & 0.532 & 0.387 & $\therefore: 4$ \\
\hline 30 & 2.544 & 0.890 & 0.650 & $\therefore \quad \therefore$ : \\
\hline 40 & 5.712 & 2.020 & 1.490 & $\because 532$ \\
\hline 50 & 10.07 & 3.750 & 2.755 & .989 \\
\hline 60 & 15.51 & 6.053 & $4.44 \%$ & 0.83 \\
\hline 70 & 21.69 & 8.898 & 6.438 & $\because \quad ? 6$ \\
\hline 80 & 28.21 & $2 \cdot$ & 8.758 & $\because 840$ \\
\hline 90 & 34.79 & 15.92 & 1.28 & 5.301 \\
\hline 100 & 41.27 & 19.92 & 3.95 & 6.880 \\
\hline 110 & 47.60 & 24.15 & 16.73 & 8.318 \\
\hline 120 & 53.74 & 28.56 & 19.56 & 10.08 \\
\hline 130 & 59.68 & 33.10 & 22.42 & $\because 46$ \\
\hline 140 & 65.36 & 37.73 & 25.28 & 15.96 \\
\hline 140 & 70.76 & 42.43 & 28.14 & $: 5.99$ \\
\hline 160 & 75.85 & 47.16 & 30.96 & $: \leqslant$, \\
\hline 170 & 80.66 & 51.90 & 33.74 & 20.32 \\
\hline 180 & 85.19 & 56.65 & 36.48 & 22.56 \\
\hline 190 & 89.45 & 61.36 & 39.15 & 24.85 \\
\hline 200 & 93.46 & 66.06 & $41.7 ?$ & $27=8$ \\
\hline 210 & 97.24 & 70.71 & 44.32 & 99.52 \\
\hline 220 & 100.8 & $75.3:$ & 46.81 & 31.89 \\
\hline 230 & 104.2 & $79.8 !$ & 49.23 & 34,28 \\
\hline 240 & 107.4 & 84.37 & 51.59 & 36.58 \\
\hline 250 & 110.5 & 88.82 & 53.88 & 3.09 \\
\hline 260 & 913.5 & 93.21 & 56.12 & $4 \div 30$ \\
\hline 270 & 196.3 & $97.5 i$ & 58.30 & 43.92 \\
\hline 280 & 119.0 & $10: .8$ & 60.41 & 46,34 \\
\hline 290 & 121.6 & 106. & 62.48 & 46.75 \\
\hline 298.15 & 123.6 & 109.4 & $64.1 \%$ & 30.72 \\
\hline 300 & 124.1 & 110.2 & 64.49 & $5,: 6$ \\
\hline 310 & 126.5 & 114.3 & 66.45 & 53.56 \\
\hline 320 & 128.8 & 118.4 & 68.36 & 55.95 \\
\hline 330 & 131.1 & 122.4 & 70.23 & 56.34 \\
\hline 340 & 133.0 & 126.3 & 72.05 & $60 . ? 2$ \\
\hline 350 & 134.9 & 130.2 & $73.8:$ & 63.09 \\
\hline
\end{tabular}
perimental reversals corrected for solid solution can be estimated with the mixing parameters of ADAMS and BISHOP (1985). Their reversed experiments on the join $\mathrm{Mg}_{2} \mathrm{SiO}_{4}-\mathrm{CaMgSiO}_{4}$ show that the miscibility gap
Table 6. Molar thermodynam1c properties of natural monticellite

$\left(\mathrm{H}_{\mathrm{T}}^{\circ}-\mathrm{H}_{\mathrm{O}}^{\circ}\right) \mathrm{I}^{2} \quad 2-\left(\mathrm{G}_{\mathrm{T}}^{\mathrm{C}}-\mathrm{H}_{0}^{\circ}\right)$

Table 7. Experimental high temperature nef capac1ty deasurements on ratural monticellite

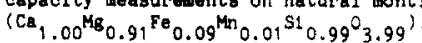

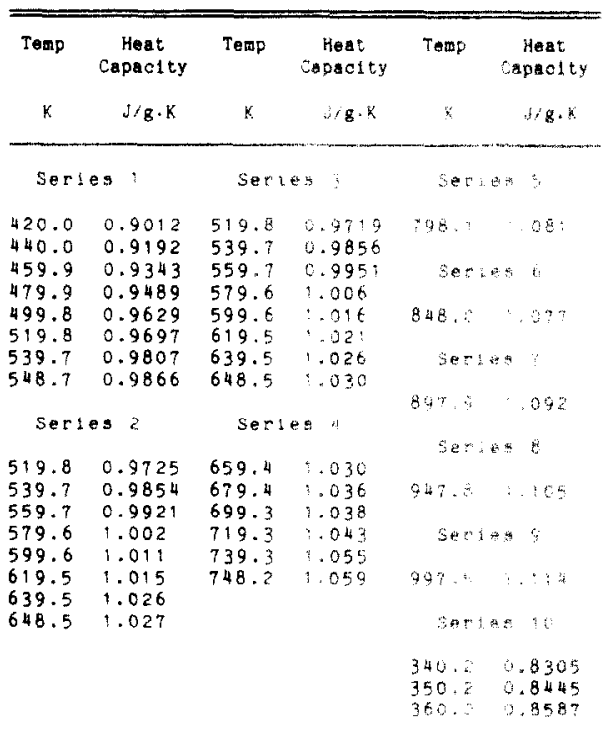


Table 8. Thermodynamic properties of 1 deal monticelilte (CaMgS1O 4 ). Formula welght 156.469

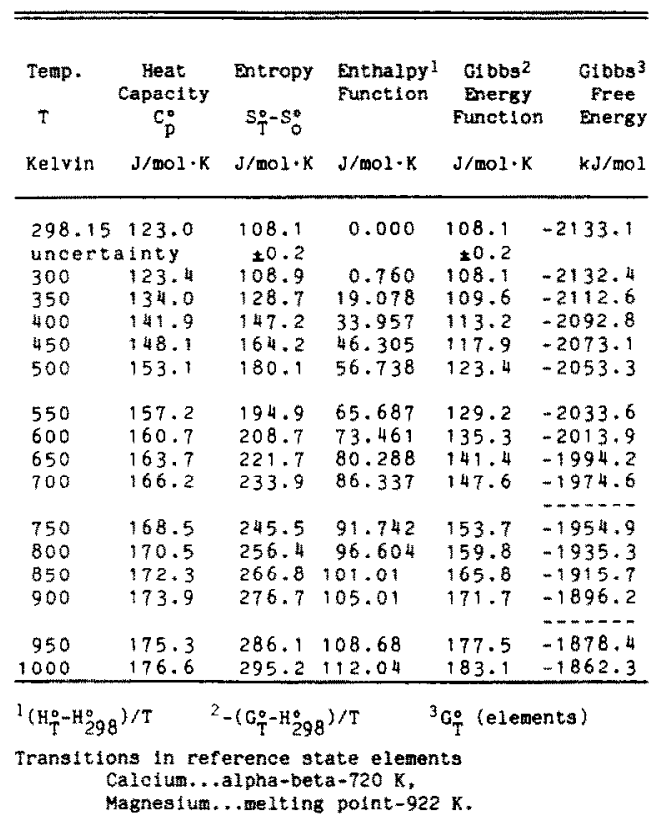

between forsterite and monticellite is independent of pressure and is asymmetric, with the monticellite limb displaying greater solid solution. Activities of monticellite and forsterite at various temperatures were calculated from the one-site asymmetric solution model of ADAMS and BISHOP (1985). At the temperatures of Yoder's experiments (Fig. 2) for reactions (2) and (5), the amount of solid solution predicted by ADAMS and BisHoP's model (e.g. $a_{\mathrm{Mo}}=0.92, a_{\mathrm{Fo}}=0.96$ at 1500 $\mathrm{K}$ ) shifts the experimental reversals significantly relative to end-member monticellite and forsterite.

The degree of solid solution for the phases akermanite and diopside in the $\mathrm{CaO}-\mathrm{MgO}-\mathrm{SiO}_{2}$ system should be minimal (KUSHIRO and SCHAIRER, 1964; SCHAIRER et al., 1967: VALLEY and ESSENE, 1980). Since the knowledge of the solid solutions is critical for proper location of the end-member reaction curves. Dr. Yoder has kindly provided the run-products of reactions (2) and (5) for analysis. The $\mathrm{X}$-ray analysis of monticellite synthesized with forsterite at $1350^{\circ} \mathrm{C}$ and $8 \mathrm{kbar}$ (Table 2) corresponds to a completely ordered olivine of composition $\mathrm{Mo}_{85} \mathrm{Fo}_{15}$ using the $a-b$ plot for Ca-Mg olivines of LUMPKIN et al. (1983). Compositions of the same sample determined by electron microprobe analyses range from $M_{82-85}$ (Table 9). The composition expected from the model of ADAMS and BISHOP (1985) is $\mathrm{Mo}_{86} \mathrm{Fo}_{14}$, in agreement with the compositions of Yoder's run products. Microprobe analyses of monticellites synthesized at lower temperatures give a much wider range of compositions. A monticellite synthesized at $975^{\circ} \mathrm{C}$ and $5 \mathrm{kbar}$ by YODER (1968), has an apparent compositional range of $\mathrm{MO}_{75-96}$ (Table 9). Back-scattered electron imaging of this monticellite shows it to contain many blebs of forsterite and some akermanite. The most monticelliterich analysis of this sample $\left(\mathrm{MO}_{96} \mathrm{FO}_{4}\right)$ corresponds precisely with the composition predicted by the Margules parameters and X-ray determinative methods of

\section{HEAT CAPACITY OF MONTICELLLITE}

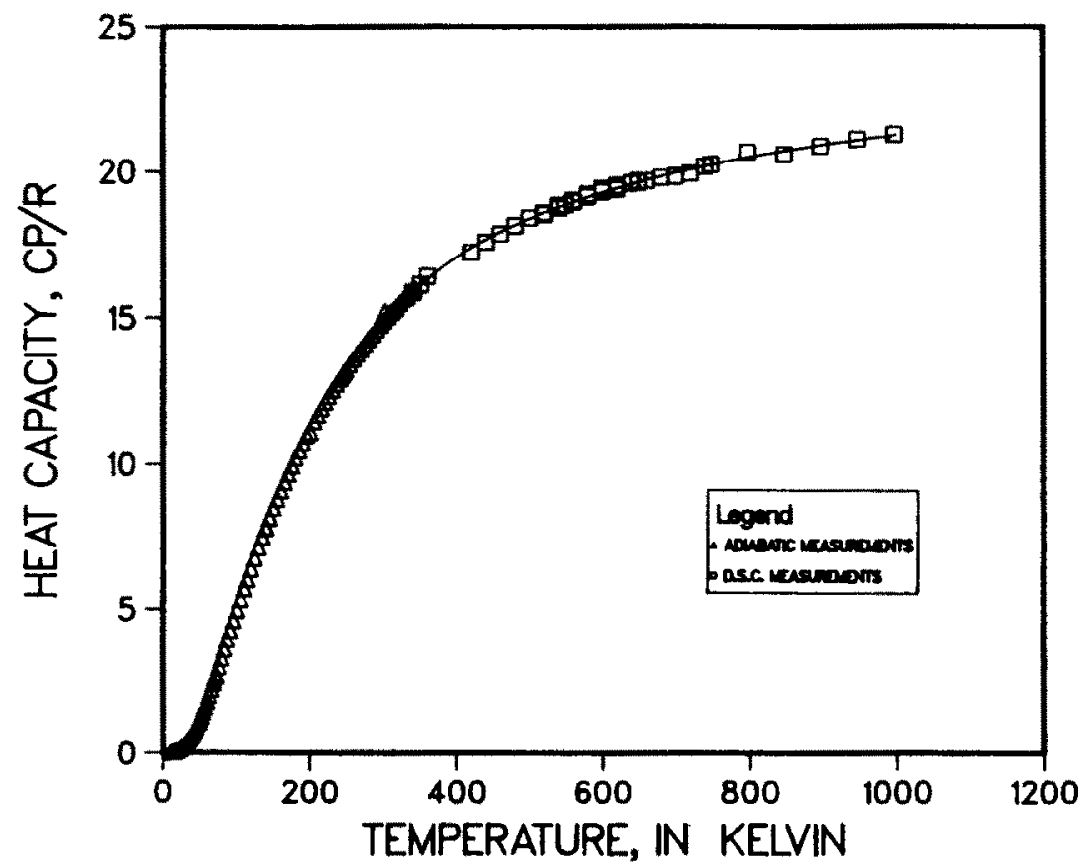

Fig. 1. Low- and high-temperature heat capacity data for natural monticellite $\left(\mathrm{Ca}_{1,00} \mathrm{Mg}_{0.91^{-}}\right.$ $\mathrm{Fe}_{0.09} \mathrm{Mn}_{0.01} \mathrm{Si}_{0.99} \mathrm{O}_{3.99}$ ). The solid line from 298 to $1000 \mathrm{~K}$ shows the smoothing function fit to the experimental data. 


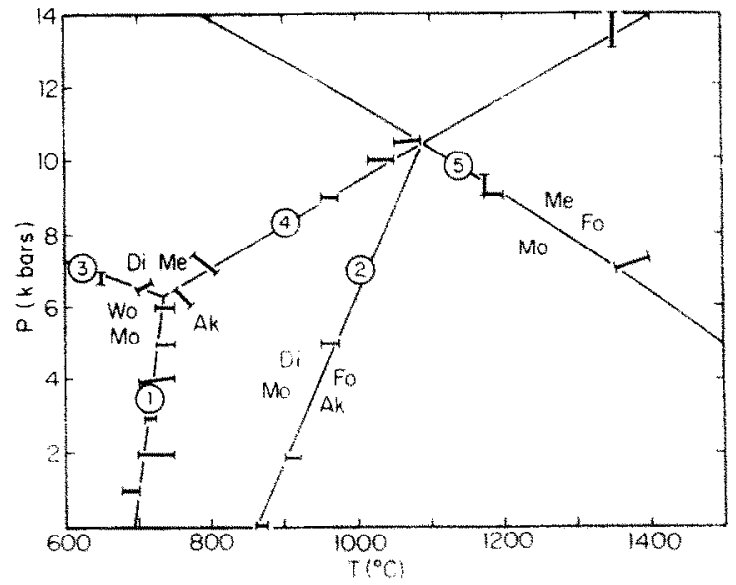

FIG. 2. Pressure-temperature diagram for reactions (1) through (5) for end-member phases, Reversed brackets for reactions (2) and (5) are corrected for solid solution. The univariant points $-F o$ and $-W o$ are located at $735^{\circ} \mathrm{C}(1008 \mathrm{~K})$ and $6.3 \mathrm{kbar}$ and $1088^{\circ} \mathrm{C}(1361 \mathrm{~K})$ and $10.2 \mathrm{kbar}$ respectively. Reversals are from the following sources: $W o+M o=A k$ (HARKER and TUTTLE, 1956: YODER, 1968); $M O+D i=F O$ $+A k$ (WALTER, 1963a; YODER, 1968); $M O=M e+F O$ (YODER, 1968); $D i+M e=A k$ (KUSHIRO and YODER, 1964; YODER, 1968); $D i+M e=W o+M o$ (YODER, 1968). Abbreviations used (as in all tables) are: $A k=$ akermanite, $C$ $=$ calcite, $D i=$ diopside, $F o=$ forsterite, $M e=$ merwinite, $M o=$ monticellite, $P e=$ periclase, $W_{0}=$ wollastonite. The reversal directly above the univariant point $-W_{o}$ is for the reaction $D i+M o=F o+A k$

ADAMS and BISHOP (1985). Analyses with greater apparent solid solution are likely due to contamination by the small forsterite inclusions. Alternatively, the variation observed in the microprobe analyses may be caused by metastable reaction products in experiments run at lower temperature and pressure.

YODER (1973, 1975) suggested that akermanite may exhibit solid solution with other phases in the $\mathrm{CaO}$ -
$\mathrm{MgO}-\mathrm{SiO}_{2}$ system. Analyses of akermanite from $\mathrm{nu}$ products show a consistent enrichment in $\mathrm{Mg}$ relative to $\mathrm{Ca}$ (Table 9), but a constant $(\mathrm{Ca}+\mathrm{Mg}) / \mathrm{Si}$ ratio of $3 / 2$ indicating no detectable solid solution toward ol. ivine. Merwinite analyses show solid solution toward forsterite with an $\mathrm{Mg} /(\mathrm{Ca}+\mathrm{Mg})$ ratio of $0.26(\mathrm{w}, 0.35$ for ideal merwinite), but the ( $\mathrm{Ca}+\mathrm{Mg} / \mathrm{Si}$ ratio of 3 suggests that merwinite has no solid solution of the $\mathrm{Ca}_{2} \mathrm{SiO}_{4}-\mathrm{Mg}_{2} \mathrm{SiO}_{4}$ join. Diopside coexisting with for sterite and monticellite may show some solid solution toward enstatite at high temperatures. The diopside analysis (Table 9) is deficient in silica. but monticellite analyzed in the same sample also shows a deficienc in silica, indicating possible analytical errors for silicon. Experiments on the akermanite-diopside join show very slight solid solution of diopside toward akermanitc at $1300^{\circ} \mathrm{C}$ (KUSHIRO and SCHAIRER, 1964), supported by VALLEY and ESSENE's (1980) analysis of diopside coexisting with akermanite from the experimental run products of YODER (1968). This solid solution requires a vacancy related substitution that is not well understood. For the purposes of this paper only the following solid solution effects involving $\mathrm{Mg}-\mathrm{Ca}$ substitutions will be considered:

1) Monticellite and forsterite exhibit mutual solid solution as defined by ADAMS and BISHOP (1985):

2) Akermanite shows $\sim 2 \% \mathrm{Mg} / \mathrm{Ca}$ enrichment, but maintains a stoichiometric $(\mathrm{Ca}+\mathrm{Mg}) / \mathrm{Si}$ ratio of $3 / 2$ :

3) Merwinite shows $3-4 \%$ solid solution toward forsterite, but maintains a $(\mathrm{Ca}+\mathrm{Mg}) /$ Si ratio of 3 .

4) Diopside shows slight solid solution toward enstatite $[\mathrm{Mg} /(\mathrm{Ca}+\mathrm{Mg})]$ and may also lie off the diopside-enstatite join toward akermanit:

For reaction (2) the shift due to solid solution can be evaluated from the equation

$$
\Delta G_{\gamma}^{p_{2}}-\Delta G_{\gamma}^{p_{1}}=\int_{p_{1}}^{p_{2}} \Delta V d P+R T \ln \frac{\left(a_{\mathrm{ak}}\right)^{*}\left(a_{\mathrm{m}}\right)^{3}}{\left(a_{\mathrm{d} i}\right)\left(a_{\mathrm{mo}}\right)^{3}}
$$

\begin{tabular}{|c|c|c|c|c|c|c|c|}
\hline $\begin{array}{l}\text { phase/run mo } \\
\mathrm{t}^{\mathrm{O}} \mathrm{C}-\mathrm{p} \text { kb } \\
\text { coex. phases ak, }\end{array}$ & $\begin{array}{c}f 0 \frac{14}{4} \\
350 / 8.0 \\
\text { ak, } 20\end{array}$ & $\begin{array}{l}m 0,150 \\
975 / 5.0 \\
a k,+0\end{array}$ & $\begin{array}{l}3 k+50 \\
1075 \% 10.5 \\
\text { ak, fo }\end{array}$ & $\begin{array}{l}\text { mo } 167 \\
1075 / 10.5 \\
7 k,+0\end{array}$ & $\begin{array}{l}80167 \\
1075,10.5 \\
a k, 80\end{array}$ & 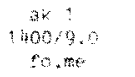 & $\begin{array}{l}\text { me } \\
400 \% 5.6 \\
\text { fo, ak }\end{array}$ \\
\hline $\begin{array}{l}38.36 \\
31.54 \\
31.2 \%\end{array}$ & $\begin{array}{r}41.82 \\
53.1: \\
4.05\end{array}$ & $\begin{array}{l}39.01 \\
27.71 \\
35.39\end{array}$ & $\begin{array}{l}43.96 \\
14.98 \\
4.15\end{array}$ & $\begin{array}{l}39.49 \\
37.16 \\
33.54\end{array}$ & $\begin{array}{r}42.50 \\
56.06 \\
2.28\end{array}$ & $\begin{array}{l}44.2 ! \\
5: 95 \\
40.48\end{array}$ & $\begin{array}{l}36.76 \\
19.6 \\
5.5\end{array}$ \\
\hline 101.02 & 98.98 & 102.11 & 100.10 & 100.18 & 100.94 & 100.45 & 100.4 \\
\hline $\begin{array}{r}0.969 \\
1.188 \\
0.843 \\
3.969\end{array}$ & $\begin{array}{l}3.001 \\
1.895 \\
0.104 \\
4.001\end{array}$ & $\begin{array}{l}0.990 \\
1.045 \\
0.962 \\
3.990\end{array}$ & $\begin{array}{r}9.991 \\
0.012 \\
1.997 \\
6.991\end{array}$ & $\begin{array}{l}1.022 \\
1.048 \\
0.930 \\
4.022\end{array}$ & $\begin{array}{l}0.999 \\
1.949 \\
0.059 \\
3.991\end{array}$ & $\begin{array}{l}1.993 \\
\because .03 \\
\approx .460 \\
\dot{1} .993\end{array}$ & $\begin{array}{r}.993 \\
.900 \\
.903 \\
7.994\end{array}$ \\
\hline $\begin{array}{lc}\text { phase/run } & \text { mo } 163 \\
T^{\circ} \mathrm{C}-\mathrm{p} \text { ko } & 175 / 10.0 \\
\text { coex. phases fo.ak }\end{array}$ & $\begin{array}{l}\text { fo } 163 \\
175 / 10.0 \\
\text { mo, ak }\end{array}$ & $\begin{array}{l}\text { me } 162 \\
1175 / 10.0 \\
\text { mo, fo, ak }\end{array}$ & $\begin{array}{l}\text { mo } 162 \\
1175 / 10.5 \\
\text { fo, ak, me }\end{array}$ & $\begin{array}{l}\text { fo } 162 \\
175 / 10.5 \\
\text { mo, ak, ne }\end{array}$ & $\begin{array}{l}\text { ak } 162 \\
1175 / 10.5 \\
\text { mo, fo, me }\end{array}$ & $\begin{array}{l}\text { tis } 120 \\
1000 / 10.0 \\
\text { tho, } 10\end{array}$ & $\begin{array}{l}\text { me: } \\
1060, \\
\text { d! f }\end{array}$ \\
\hline $\begin{array}{l}39.17 \\
33.79 \\
28.53\end{array}$ & $\begin{array}{r}42.23 \\
55.16 \\
4.00\end{array}$ & $\begin{array}{l}36.84 \\
13.40 \\
49.39\end{array}$ & $\begin{array}{l}38.19 \\
30.9 ? \\
29.11\end{array}$ & $\begin{array}{r}42.3^{4} \\
55.72 \\
3.89\end{array}$ & $\begin{array}{l}44.15 \\
15.15 \\
40.70\end{array}$ & $\begin{array}{l}53.50 \\
59.6 \\
6.6\end{array}$ & $\begin{array}{l}37.6 \\
25.7 \% \\
3.8 .8\end{array}$ \\
\hline 99.49 & 101.39 & 99.64 & $9 \overline{98.22}$ & 101.95 & 100.00 & 97.17 & $100.2 ?$ \\
\hline $\begin{array}{l}1.004 \\
1.214 \\
0.783 \\
4.003\end{array}$ & $\begin{array}{l}0.984 \\
1.916 \\
0.100 \\
3.984\end{array}$ & $\begin{array}{l}2.014 \\
1.092 \\
2.893 \\
8.014\end{array}$ & $\begin{array}{l}0.992 \\
1.197 \\
0.810 \\
3.992\end{array}$ & $\begin{array}{l}0.980 \\
1.923 \\
0.096 \\
3.980\end{array}$ & $\begin{array}{l}2.000 \\
1.023 \\
1.976 \\
7.000\end{array}$ & $\begin{array}{l}1.935 \\
1.057 \\
.008 \\
.735\end{array}$ & $\begin{array}{l}0.96 \\
.10 \% \\
0.932 \\
3.96 ?\end{array}$ \\
\hline
\end{tabular}


The shift in the other reactions due to solid solution can be estimated with similar equations. Akermanite, merwinite and diopside activities are taken as atom fraction over all octahedral sites. For reactions (2) and (4), the effects of solid solution for akermanite, merwinite and diopside tend to cancel each other and the net shift for both reactions is less than 0.1 kbar. For reaction (5), the solid solution between monticellite, forsterite and merwinite places the theoretical endmember reversal brackets at significantly higher pressures ( $2 \mathrm{kbar}$ at $1400^{\circ} \mathrm{C}$ ).

The effect of solid solution for the location of the decarbonation reaction reversals is very small at the temperature of the experiments. With the constraints of the reversal brackets corrected for solid solution, the $P-T$ location of reactions (1-5) for the ideal phases was calculated with the aid of the computer program EQUILI (WALL and ESSENE, unpublished) from the relation

$$
\Delta G_{T_{2}}^{P_{2}}-\Delta G_{T_{1}}^{P_{1}}=\int_{P_{1}}^{P_{2}} \Delta V d P-\int_{T_{1}}^{T_{2}} \Delta S d T .
$$

Data for all phases are given in Table 10. The two solid-solid reaction invariant points, forsterite-absent $(-\mathrm{Fo})$ and wollastonite-absent $(-\mathrm{Wo})$ in Fig. 2 are located at $1008 \pm 5 \mathrm{~K}$ and $6.3 \pm 0.1$ kbar and $1361 \pm 10$ $\mathrm{K}$ and $10.2 \pm 0.2 \mathrm{kbar}$ respectively. The entropies of all phases considered are now well-known except for merwinite, which has only been measured down to 52 K (WELLER and KELLEY, 1963). The entropy estimate of WELLER and KELLEY for merwinite results in a poor fit of the generated curves to the experimental reversals corrected for solid solution. A best fit is made when the $S_{298}^{0}$ of merwinite is set at $250.2 \mathrm{~J} \cdot \mathrm{mol}^{-1} \mathrm{~K}^{-1}$. less than WELLER and KELLEY's estimate of $253.2 \mathrm{~J} \cdot \mathrm{mol}^{-1}$ $\mathrm{K}^{-1}$. WELLER and KELLEY (1963) noted a small transition at $122 \mathrm{~K}$ which may be due to a phase transition or contamination by other phases. The X-ray pattern of their synthetic merwinite had two peaks that do not correspond to merwinite. The discrepancy between the measured and calculated entropy of merwinite may be due to possible contamination by other phases and to errors in the extrapolation of WELLER and KELLEY's (1963) heat capacity from 50 to $0 \mathrm{~K}$.

The best fit of reactions $(1-5,11-15)$ to the experimental reversals and the $\Delta G_{298}^{0}$ of each phase was determined in the following way:

1) The $\Delta G_{298}^{0}$ was calculated for each reaction (1$5,11-15)$ from the reversals at high $P-T$. For the decarbonation reactions, using the modified RedlichKwong model of KERRICK and JACOBS (1981) for $\mathrm{H}_{2} \mathrm{O}$ $\mathrm{CO}_{2}$ mixing, the experiments with pure $\mathrm{CO}_{2}$ and at low pressures are inconsistent with the experiments with $\mathrm{H}_{2} \mathrm{O}-\mathrm{CO}_{2}$ mixtures at 1 kbar.

2) Simultaneous calculation does not yield a unique solution for the $\Delta G_{298}^{0}$ of each phasc. The $\Delta G_{298}^{0}$ of $\mathrm{CO}_{2}$, calcite, periclase and wollastonite were assumed to be correct (ROBINSON et al., 1982; TREIMAN and ESSENE, 1983), and with these data the $\Delta G_{298}^{0}$ of the remaining phases were calculated.

The best fit for reactions $(1-5,11-15)$ is shown in Figs. $2-4$ using the thermodynamic data in Table 10. The free energy of monticellite $\left(\Delta G_{298}^{0}\right)$ is calculated as $-2133 \mathrm{~kJ} \cdot \mathrm{mol}^{-1}$, significantly less than previously re-

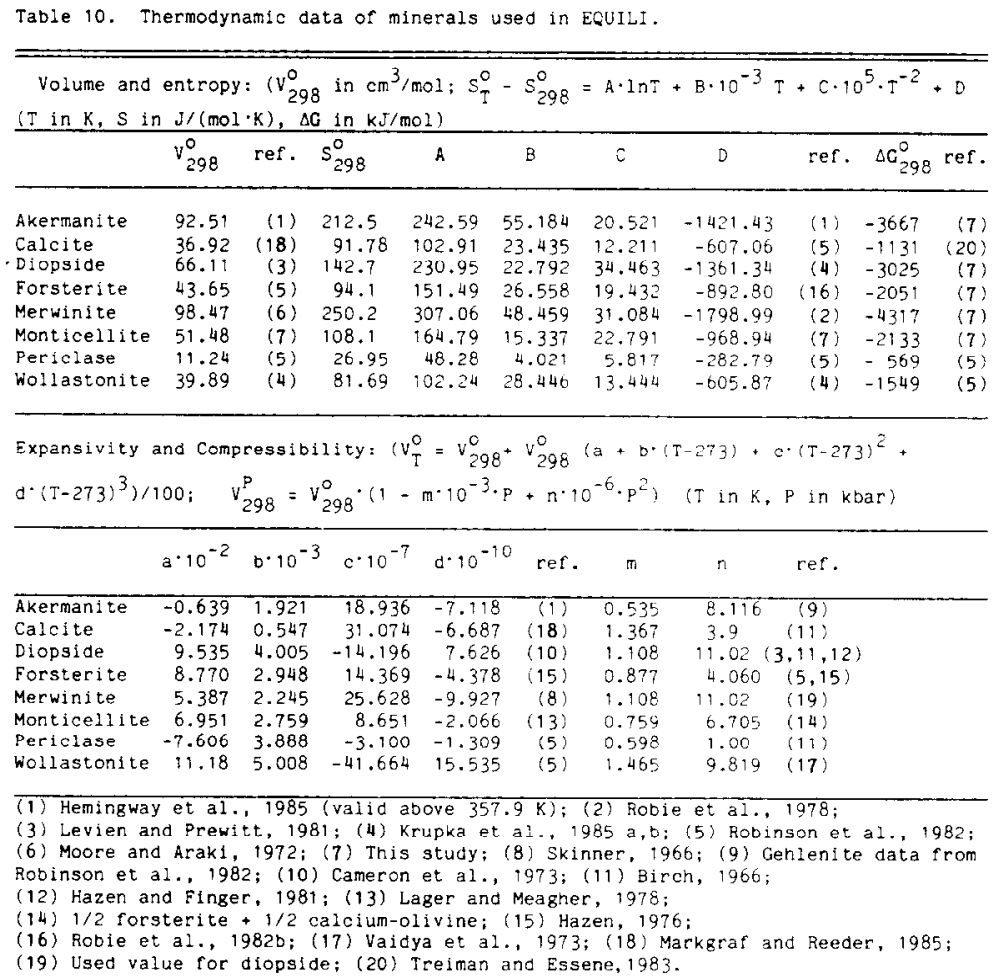




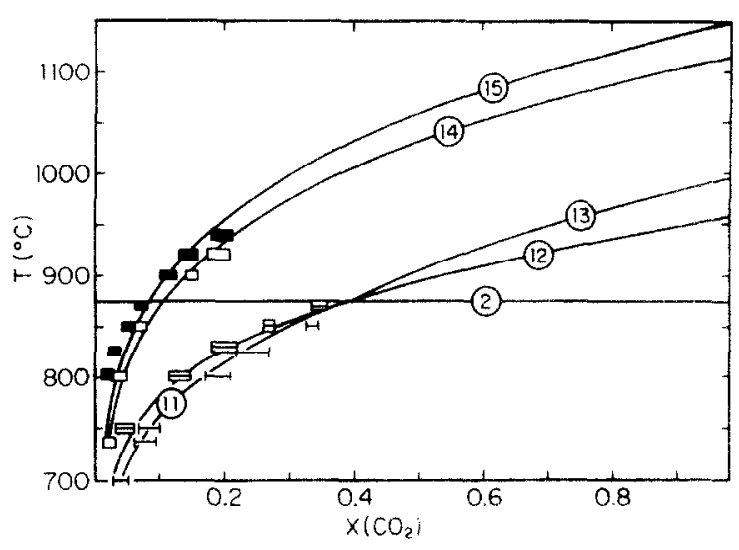

FIG. 3. Temperature- $X\left(\mathrm{CO}_{2}\right)$ diagram at 1 kbar total pressure. Reversals are from ZHARIKOV et al. 1977. Reaction numbers are as follows: (2) $D i+M o-F o+A k$, (11) Fo $+D i$ $+C c=M o+C_{2}$, (12) $D i+C c=A k+C_{2}$, (13) $A k+F o$ $+C c=M o+\mathrm{CO}_{2},(14) F o+C c=M o+P e+\mathrm{CO}_{2},(15)$ $\mathrm{Ak}+\mathrm{Cc}=\mathrm{Me}+\mathrm{CO}_{2}$. See Fig. 2 for abbreviations.

ported (HELGESON et al., 1978, $-2143 \mathrm{~kJ} \cdot \mathrm{mol}^{-1}$ and ROBIE et al., $\left.1978,-2146 \mathrm{~kJ} \cdot \mathrm{mol}^{-1}\right)$. The close agreement between their two estimates is a result of their use of the same enthalpy data for monticellite. More recent enthalpy measurements on monticellite by alkali borate solution calorimetry at $1073 \mathrm{~K}$ (BRousse et al, 1984) were extrapolated to $298 \mathrm{~K}$ with the new entropy data. The $\Delta G_{298}^{0}(M o)$ value of $-2129 \mathrm{~kJ} \cdot \mathrm{mole}^{-1}$ is in excellent agreement with the present results.

The $\Delta G_{298}^{0}$ calculated for akermanite is -3667 $\mathrm{kJ} \cdot \mathrm{mol}^{-1}$ compared to $-3681,-3679$, and -3668 $\mathrm{kJ} \cdot \mathrm{mol}^{-1}$ of HELGESON et al. (1978), ROBIE et al. (1978), and HEMINGWAY et al. (1985) respectively. The $\Delta G_{1000 \mathrm{~K}}^{0}(A k)=-3218$ value is in good agreement with the $\Delta G_{1000 \mathrm{~K}}^{0}(A k)=-3210 \mathrm{~kJ} \cdot \mathrm{mol}^{-1} \mathrm{~K}^{-1}$ determined from the solution calorimetry data of BROUSSE $e t$ al. (1984). The calculated $\Delta G_{298}^{0}$ for merwinite is -4317 $\mathrm{kJ} \cdot \mathrm{mol}^{-1}, 0.5 \%$ less than the estimates of -4339 $\mathrm{kJ} \cdot \mathrm{mole}^{-1}$ from RoBIE et al. (1978) and -4340 $\mathrm{kJ} \cdot \mathrm{mol}^{-1}$ from HELGESON el al. (1978), and $0.2 \%$ greater than the estimate of $-4307 \mathrm{~kJ} \cdot \mathrm{mol}^{-1}$ calculated from the high-temperature enthalpy data of BROUSSE et al. (1984) and the entropy data in Table 10. Reaction (5) is located 2.5 kbar higher than the best fit location at $1200^{\circ} \mathrm{C}$ using the enthalpy data of BRousse et al. (1984). This illustrates the uncertainties in locating solid-solid reactions with enthalpy data alone. An error of just $0.2 \%$ in the enthalpy of a phase can result in a significant error in the location of a reaction curve. For these reactions, measured thermodynamic quantities must be combined with the experimental reversals to yield accurate results.

The locations of the univariant reactions $(1-5,11-$ 15), calculated from the data in Table 10 are in excellent agreement with all of the experimental reversals (Figs. 2-4) except for reactions (14) and (15) (Fig. 4). The apparent reversals for reactions $(11-14)$ (WALTER, 1963a,b) nearly coincide, while the calculated positions for these curves indicate that reaction (14) must lie at higher temperatures than the other three (Fig. 4). This same conclusion was reached by TURNER (1968. p 135 ) on the basis of natural occurrences and thermodynamic calculations.

Phase equilibria in the system $\mathrm{CaO}-\mathrm{MgO}-\mathrm{SiO}_{2}-\mathrm{CO}$. are pertinent to calc-silicates metamorphosed at high temperatures and low pressures. Monticellite, aker manite, merwinite, and monticellite + periclase are all stable in the pyroxene-hornfels facies. Their stability is controlled primarily by $P\left(\mathrm{CO}_{2}\right)$ and they provide far better $\mathrm{CO}_{2}$ barometers than thermometers.

Although there are many reports of high-temperature $\mathrm{Ca}-\mathrm{Mg}$ silicates, few authors have systematically described the sequence of high-temperature assemblages around a contact aureole. JOESTEN $(1974,1976)$ reports assemblages of $\mathrm{Ca}$ - and $\mathrm{Ca}-\mathrm{Mg}$ silicates in a limestone sequence intruded by a high-level gabbro. He infers temperatures of $900-1000^{\circ} \mathrm{C}$ based on phase equilibria involving calc-silicates (see also TREIMAN and ESSENE, 1983). JOESTEN (1976) reports a melilite $\left(A k_{30}\right)-C(-M$ assemblage which is buffered by reaction (15) for given $a(A k)$ and $f\left(\mathrm{CO}_{2}\right)$. He a'so reports spurrite-rankinite-wollastonite in skarns. These two assemblages may indicate skarn formation at water-rich conditions $\left(X\left(\mathrm{H}_{2} \mathrm{O}\right)=0.8-0.95\right)$ and lower temperatures $(850$ $900^{\circ} \mathrm{C}$ ) than inferred by JOESTEN. These water-rich conditions are also expected for the formation of vesuvianite (VALLEY et al. 1985) which is widespread in the skarn studied by JOESTEN. Independent thermometry is needed before more precise fluid compositions can be reliably obtained.

BOWEN (1940) estimated the relative abundance of phases in the system $\mathrm{CaO}-\mathrm{MgO}-\mathrm{SiO}_{2}-\mathrm{CO}_{2}$ by correlating the abundance of each mineral to its year of discovery. Diopside was named in 1806, wollastonite in 1822, forsterite in 1824, monticellite in 1831, aker. manite in 1884 and merwinite in 1921, and the low. temperature calorimetry for each of these phases has to date been measured in the same order. Merwinite was the last named and it remains the only one in this

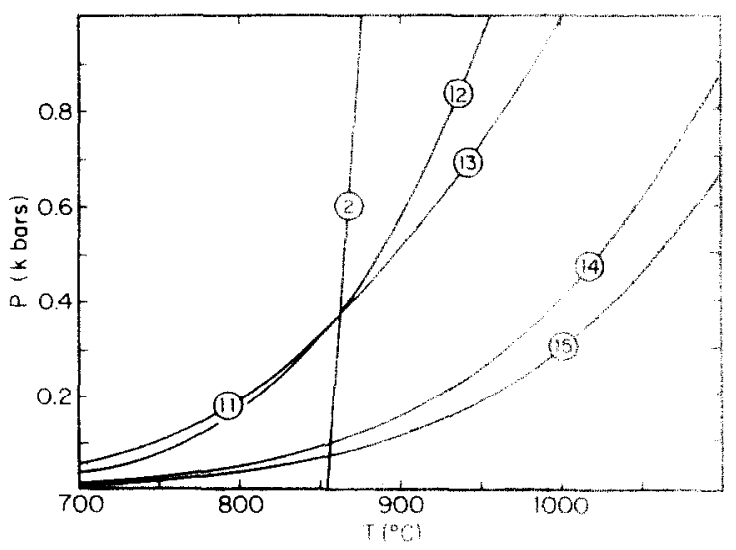

FIG. 4. Pressure-temperature diagram for decarbonation reactions. See Fig. 3 for reaction numbers. Reactions $(11-13)$ coincide with the experimental reversals of WAL TER (1963a). Reactions (14-15) are located at higher temperatures than the reversals of WALTER (1963b) and SHMULOVICH (1969). 
group that does not have low-temperature calorimetry measurements.

Acknowledgements-Research was funded in part by NSF grants EAR-8009538 to E.J.E. and E.F.W. and also EAR8212764 and EAR-8408168 to E.J.E. We are grateful to Dr. Wilbur C. Bigelow and Mr. Carl E. Henderson for maintaining the electron microprobe facilities at The University of Michigan. A preprint of G. E. Adams and F. E. Bishop's manuscript was greatly appreciated. We are especially grateful to Dr. Hatten S. Yoder, Jr. for allowing us to analyze his run products and for his early review of the manuscript. The reviews of G. E. Adams, F. B. Bishop, J, M. Ferry, H. T. Haselton, Jr., R. A. Rubie, G. R. Robinson, Jr. and A. H. Treiman proved to be very helpful. The first author thoroughly enjoyed enlightening discussions with S. W. Sharp.

Editorial handling: J. M. Ferry

\section{REFERENCES}

ADAMS G. E. and Bishop F. B. (1985) An experimental investigation of thermodynamic mixing properties and unitcell parameters of forsterite-monticellite solid solution. Amer Mineral 70, 714-722.

BigGar G. M. and O'HARA M. J. (1969) Monticellite and forsterite crystalline solutions. J. Amer. Ceram. Soc. 52, 249-252.

BIRCH F. (1966) Compressibility: elastic constants. In Handbook of Physical Constants (ed. S. P. CLARK, JR.), pp. 97174. Geological Society America Memoir 97.

Bowen N. L. (1940) Progressive metamorphism of siliceous limestones and dolomite. J. Geol. 68, 225-274.

Brousse C., NEWTON R. C. and KLEPPA O. J. (1984) Enthalpy of formation of forsterite, enstatite, akermanite, monticellite and merwinite at $1073 \mathrm{~K}$ determined by borate solution calorimetry. Geochim. Cosmochim. Acta 48, 10811088.

Brown G. E., JR. (1982) Olivine and silicate spinels. In Orthosilicates (ed. P. H. RIBBE), pp. 275-381. Mineralogical Society of America.

Cameron M., Sueno S., Prewitt C. T. and Papike J. J. (1973) High-temperature crystal chemistry of acmite, diopside, hedenbergite, jadeite, spodumene, and ureyite. Amer. Mineral. 58, 594-618.

FRANCIS C. A. (1985) New data on the forsterite-tephroite series. Amer. Mineral. 70, 568-575.

FranCIS C. A. and RIBBE P. H. (1980) The forsterite-tephroite series: I. Crystal structure refinements. Amer. Mineral. 65, $1263-1269$.

HARKER R. J. and TUtTLE O. F. (1956) The lower limit of stability of akermanite $\left(\mathrm{Ca}_{2} \mathrm{MgSi}_{2} \mathrm{O}_{7}\right)$. Amer. J. Sci. 254, 468-478.

HAZEN R. M. (1976) Effects of temperature and pressure on the crystal structure of forsterite. Amer. Mineral. 61, 12801293.

HAZEN R. M. and FINGER L. W. (1981) Crystal structure of diopside at high temperature and pressure. Carnegie Inst Wash. Yearb. 80, 373-376.

Helgeson H. C., Delany J. M., NesBitt H. W. and Bird D. K. (1978) Summary and critique of the thermodynamic properties of rock-forming minerals. Amer. J. Sci. 278-A, $1-229$.

Hemingway B. S., KRUPKA K. A. and RobiE R. A. (1981) Heat capacity of the alkali feldspars between 350 and 1000 $\mathrm{K}$ from differential scanning calorimetry, the thermodynamic functions of the alkali feldspars from 298.15 to 1400 $\mathrm{K}$, and the reaction quartz + jadeite $=$ analbite. Amer . Mineral. 66, 1202-1216.

Hemingway B. S., Evans H. T., JR., Nord G. L., JR., HasELtoN H. T., JR., ROBIE R. A. and MCGEE J. J. (1986) A study of phase transitions in the heat capacity and thermal expansion of akermanite, $\mathrm{Ca}_{2} \mathrm{MgSi}_{2} \mathrm{O}_{7}$. and revised values for the thermodynamic properties of akermanite. Can. Mineral. (in press).

JOESTEN R. (1974) Metasomatism and magmatic assimilation at a gabbro-limestone contact, Christmas Mountains. Big Bend Region. Texas. Ph.D. dissertation. California Institute of Technology.

JOESTEN R. (1976) High-temperature contact metamorphism of carbonate rocks in a shallow crustal environment. Christmas Mountain. Big Bend region, Texas. Amer. Mineral. 61, 776-781.

KERRICK D. M. and JACOBS G. K. (1981) A modified RedlichKwong equation for $\mathrm{H}_{2} \mathrm{O} . \mathrm{CO}_{2}$, and $\mathrm{H}_{2} \mathrm{O}-\mathrm{CO}_{2}$ mixtures at elevated pressures and temperatures. Amer. J. Sci. 281, 735767.

KRUPKA K. M., HeMingWAY B. S.. ROBIE R. A. and KERRICK D. M. (1985a) High-temperature heat capacities and derived thermodynamic properties of anthophyllite, diopside. dolomite, enstatite, bronzite, talc, tremolite and wollastonite. Amer. Mineral. 70, 261-271.

Krupka K. M., Robie R. A., Hemingway B. S., Kerrick D. M. and ITO J. (1985b) Low-temperature heat capacities and derived thermodynamic properties of anthophyllite. diopside, enstatite, bronzite, and wollastonite. Amer. Mineral. 70, 249-260.

Kushiro I. and SChairer J. F. (1964) The join diopsideakermanite. Carnegie Inst. Wash. Yearb. 63, 132-133.

KUSHIRO I. and YODER H. S.. JR. (1964) Breakdown of monticellite and akermanite at high pressures. Carnegie Inst. Wash. Yearb. 63, 81-83.

LAGER G. A. and MEAGHeR E. P. (1978) High-temperature structural study of six olivines. Amer. Mineral. 63, 365377.

LEVIEN L. and PREwITT C. T. (1981) High-pressure structural study of diopside. Amer. Mineral 66, 315-323.

LUMPKIN G. R. and RIBBE P. H. (1983) Composition, orderdisorder and lattice parameters of olivines: relationships in silicate, germanate, beryllate, phosphate and borate olivines. Amer. Mineral. 68, 164-176.

LuMPKIN G. R., RibBe P. H. and LuMPKIN N. E. (1983) Composition, order-disorder and lattice parameters of olivines: determinative methods for $\mathrm{Mg}-\mathrm{Mn}$ and $\mathrm{Mg}$-Ca silicate olivines. Amer. Mineral. 68, 1174-1182.

MARKGRAF S. A. and REEDER R. J. (1985) High-temperature structure refinements of calcite and magnesite. Amer. Mineral. 70, 590-600.

MOORE P. B. and ARAKI T. (1972) Atomic arrangement of merwinite, $\mathrm{Ca}_{3} \mathrm{Mg}\left(\mathrm{SiO}_{4}\right)_{2}$, an unusual dense-packed structure of geophysical interest. Amer. Mineral. 57, 1355-1374.

Mukhopadhyay D. K. and Lindsley D. H. (1983) Phase relations in the join kirschsteinite $\left(\mathrm{CaFeSiO}_{4}\right)$-fayalite $\left(\mathrm{Fe}_{2} \mathrm{SiO}_{4}\right)$. Amer. Mineral. 68, 1089-1094.

ONKEN H. (1964) Verfeinerung der Kristallostruktur von Monticellite. Naturwissenschafien 51, 334.

Robie R. A.. Hemingway B. S. and Fisher J. R. (1978) Thermodynamic properties of minerals and related substances at $298.15 \mathrm{~K}$ and 1 bar ( $10^{5}$ pascals) pressure and at higher temperatures. U. S. Geol. Surv. Bull. 1452, $456 \mathrm{p}$. (reprinted with corrections).

Robie R. A., Finch C. B. and Hemingway B. S. (1982a) Heat capacity and entropy of fayalite $\left(\mathrm{Fe}_{2} \mathrm{SiO}_{4}\right)$ between 5.1 and $383 \mathrm{~K}$ : comparison of calorimetric and equilibrium values for the QFM buffer reaction. Amer. Mineral. 67, 463-469.

Robie R. A.. Hemingway B. S. and TAKel H. (1982b) Heat capacities and entropies of $\mathrm{Mg}_{2} \mathrm{SiO}_{4}, \mathrm{Mn}_{2} \mathrm{SiO}_{4}$, and $\mathrm{Cu}_{2} \mathrm{SiO}_{4}$ between 5 and $380 \mathrm{~K}$. Amer. Mineral 67, 470-482.

ROBINSON G. R., JR. and HAAS J. L., JR. (1983) Heat capacity, relative enthalpy, and calorimetric entropy of silicate minerals: an empirical method of prediction. Amer. Mineral. 68, 541-554.

RoBinSON G. R., JR., HAAS J. L., JR., SCHAFER C. M. and HASELTON H. T.. JR. (1982) Thermodynamic and ther- 
mophysical properties of selected phases in the $\mathrm{MgO}_{-} \mathrm{SiO}_{2}$ $\mathrm{H}_{2} \mathrm{O}-\mathrm{CO}_{2}, \mathrm{CaO}-\mathrm{Al}_{2} \mathrm{O}_{3}-\mathrm{SiO}_{2}-\mathrm{H}_{2} \mathrm{O}-\mathrm{CO}_{2}$, and $\mathrm{Fe}-\mathrm{FeO}-\mathrm{Fe}_{2} \mathrm{O}_{3}$ $\mathrm{SiO}_{2}$ chemical systems, with special emphasis on the properties of basalts and their mineral components. $U . S$. Geol. Surv. Open-File Rept. 83-79, 429 p.

SCHAIRER J. F., YODER H. S., JR. and TILLEY C. E. (1967) The high-temperature behaviour of synthetic melilites on the join gehlenite-soda melilite-akermanite. Carnegie Inst Wash. Yearb. 65, 217-226.

SHMULOVICH K. I. (1969) Stability of merwinite in the system $\mathrm{CaO}-\mathrm{MgO}-\mathrm{SiO}_{2}-\mathrm{CO}_{2}$. Doklady, Earth Sci. Sect. 184, 125127.

SKINNER B. J. (1966) Thermal expansion. In Handbook of Physical Constants. (ed. S. P. Clark, JR., pp. 75-96. Geological Society America Memoir 97.

Treiman A. H. and EsSENE E. J. (1983) Phase equilibria in the system $\mathrm{CaO}-\mathrm{SiO}_{2}-\mathrm{CO}_{2}$. Amer. J. Sci. 283-A, 97-121

TURNER F. J. (1968) Metamorphic Petrology. McGraw-Hill, Inc. 1st edn. $403 \mathrm{p}$.

Vaidya S. N., Bailey S., Pasternack T. and Kennedy G. C. (1973) Compressibility of fifteen minerals to $45 \mathrm{kil}$ obars. J. Geophys. Res. 78, 6893-6898.

VALLEY J. W. and ESSENE E. J. (1980) Akermanite in the Cascade Slide Xenolith and its significance for regional metamorphism in the Adirondacks. Contrib. Mineral. $P_{e}$. trol. 74, 143-152.

VALley J. W., PEaCor D. R., Bowman J. R., ESSENE E. J. and ALLARD M. J. (1985) Crystal chemistry in the system $\mathrm{CaO}-\mathrm{MgO}-\mathrm{Al}_{2} \mathrm{O}_{3}-\mathrm{SiO}_{2}-\mathrm{H}_{2} \mathrm{O}-\mathrm{CO}_{2}$. J. Metamorphic Geol. 3, 137-153.

WALTER L. S. (1963a) Experimental studies on Bowen's decarbonation series: Part I: P-T univariant equilibria of the "monticellite" and "akermanite" reactions. Amer. J. Sci 261, 488-500.

WALTER L. S. (1963b) Experimental studies on Bowen's decarbonation series: Part II: P-T univariant equilibria of the reaction: forsterite + , calcite $=$ monticelilte + periclase $+\mathrm{CO}_{2}$. Amer. J. Sci. 261, 773-779.

WARNER R. D. and LUTH W. C. (1973) Two-phase data for the join monticellite $\left(\mathrm{CaMgSiO}_{4}\right)$-forsterite $\left(\mathrm{Mg}_{2} \mathrm{SiO}_{4}\right)$ : ex perimental results and numerical analysis. Amer. Mineral 58, 998-1008.

WELLER W. W. and KeLLEY K. K. (1963) Low-temperature heat capacities and entropies at $298.15^{\circ} \mathrm{K}$ of akermanite cordierite, gehienite, and merwinite. $L . S$. Bur. Mines Rept Inv. $6343,7 \mathrm{p}$.

Westrum E. F., Furukawa G. T. and MCCullough J. P. (1968) Adiabatic low temperature calorimetry. In Experi mental Thermodynamics (eds. J. P. MCCullovGH AND D. W. SCOTT). Vol. 1, pp. 133-214. Butterworths and $\mathrm{Co}$. Ltd.

Westrum E. F., JR. (1984) Computerized adiabatic thermophysical calorimetry. In Proceedings NATO Advanced Study Institute on Thermochemistry at liana de Castello. Portugal (ed. M. A. V. Riberio DA Silva). pp. 745-776 New York

YANG H. Y. (1973) New data on forsterite and monticellite solid solutions. Amer. Mineral. 58, 343-345.

YODER H. S., JR. (1968) Akermanite and related melilite bearing assemblages. Carnegie Inst. W'ash. Yearb. 66, 47 ! 477.

YODER H. S., JR. (1973) Melilite stability and paragenesis Fortschr. Mineral. 50, 140-173.

YODER H. S., JR. (1975) Relationship of melilite-bearing rocks to kimberlite: a preliminary report on the system akermanite- $\mathrm{CO}_{2}$. Phys. Chem. Earth 9, 883-894

Zharikov V. A., Shmulovich K. I. and Bulatov V. K. (1977) Experimental studies in the system CaO-MgO$\mathrm{Al}_{2} \mathrm{O}_{3}-\mathrm{SiO}_{2}-\mathrm{CO}_{2}-\mathrm{H}_{2} \mathrm{O}$ and conditions of high-temperature metamorphism. In Experimental Petrology Related to Ex. treme Metamorphism (ed. D. H. GREEN). Tectonophysic 43, $145-162$. 